\title{
DISCURSO RELIGIOSO, SUS LÍMITES Y JURISPRUDENCIA EUROPEA: EL CASO CONNOLLY (2007)
}

\author{
[Religious Speech, its Limits and Domestic European Case-Law: \\ The Connolly Case (2007)]
}

RODRIGO CÉSPEDES²

\begin{abstract}
RESUMEN
El caso comentado trata de una campaña anti-aborto y la contracepción de emergencia muy agresiva. El principal asunto a decidir es si esta acción se encuentra protegida por la libertad religiosa y de expresión. La Corte decidió que la libertad de expresión, incluso cuando se trata de un discurso protegido también por la libertad religiosa, puede válidamente ser restringida cuando es claramente ofensivo y tiene como propósito directo causar angustia en el receptor.

Palabras clave: libertad religiosa, libertad de expresión, discurso religioso, aborto, píldora del día después

ABSTRACT

The commented case deals with an aggressive campaign against abortion and the day-after-pill. The main issue at stake is whether that kind of speech IS protected by freedom of religion and expression. The Court decided that religious speech can be restricted when it is clearly offensive and the purpose of its exercise is to cause distress on the recipients.

Keywords: Freedom of religion, freedom of expression, religious speech, abortion, day-after pill
\end{abstract}

DOI: $10.7764 / R L D R .8 .98$

\section{HECHOS}

Veronica Connolly, una activista católica contra el aborto, envió fotos muy gráficas y crudas de fetos abortados a tres farmacias que vendían la píldora del día después.3 La

\footnotetext{
${ }^{1}$ Connolly v DPP [2007] EWHC 237 (Admin); [2008] 1 W.L.R. 276, High Court of Justice, Queen's Bench Division, Administrative Court.

${ }^{2}$ Research fellow, Max Planck Institute for Social Anthropology (Halle), Department of Law and Anthropology. CUREDI project. E-mail: cespedes@eth.mpg.de
} 
Rodrigo Céspedes. Discurso religioso, sus límites y jurisprudencia europea: el caso Connolly (2007).

activista se oponía a la píldora del día después porque, en su opinión era abortiva; por ende, en contra del derecho básico a la vida, esencial en la doctrina cristiana. Connolly fue sometida a proceso utilizando la Ley de Comunicaciones Maliciosas inglesa (1988).4 La imputada fue declarada culpable de delitos tipificados en esa ley, por el envío de información "manifiestamente ofensiva o indecente" con la precisa intención de "de provocar angustia o ansiedad" a los destinatarios. Connolly apeló, argumentando que las imágenes no eran manifiestamente ofensivas o indecentes y sólo ejerció su derecho a protestar en contra de ese tipo de contracepción de emergencia en base a su fe católica. En opinión de la recurrente, su condena había violado su derecho a la libertad de expresión, que ejercía para manifestar sus creencias religiosas, derechos protegidos en los Artículos 95 y 106 de la Convención Europea de Derechos Humanos (CEDH).

${ }^{3}$ La píldora del día después forma parte de lo que se denomina "contracepción poscoital" o "anticoncepción de emergencia". Estos métodos se ponen en práctica después de las relaciones sexuales. Existe duda si éstos impiden la ovulación o fertilización, o van más allá y previenen la implantación de un embrión en el útero, interrumpiendo el embarazo. Esta duda plantea asuntos éticos por lo que la pastilla no se comercializa en todos los países. El asunto ocasionó un intenso debate judicial en Chile con pronunciamientos de la Corte Suprema y el Tribunal Constitucional.

${ }^{4}$ La 1988 Malicious Communications Act sanciona el envío de correo que ocasione angustia o ansiedad (incluye también medios electrónicos). Esto es lo que se denomina hate mail (un tipo de acoso que consiste en una comunicación amenazante hacia el destinatario por su lenguaje abusivo, obsceno o hiriente, que también puede ser on-line). Este delito pertenece al género del hate speech (el discurso que tiene como único fin promover la discriminación, alentar la violencia y atentar contra la dignidad de un grupo de personas), que a su vez es una especie de hate crime (delito que se motiva exclusivamente por la animadversión del agresor a la víctima porque ésta pertenece a un determinada categoría por su género, religión, etnia, orientación sexual, nacionalidad, etc.). En el caso chileno, la Ley Zamudio (Nro. 20.609/2012) introdujo modificaciones al Código Penal (su Artículo 12) y agregó una nueva agravante de responsabilidad: la circunstancia en la cual la comisión del delito es motivada por discriminación. Hay una regulación similar en México, la "Ley Federal para Prevenir y Eliminar la Discriminación" (2003); en Brasil hay varias regulaciones, incluida la constitución, con contenido similar.

5 “Artículo 9. Libertad de pensamiento, de conciencia y de religión 1. Toda persona tiene derecho a la libertad de pensamiento, de conciencia y de religión; este derecho implica la libertad de cambiar de religión o de convicciones, así como la libertad de manifestar su religión o sus convicciones individual o colectivamente, en público o en privado, por medio del culto, la enseñanza, las prácticas y la observancia de los ritos. 2. La libertad de manifestar su religión o sus convicciones no puede ser objeto de más restricciones que las que, previstas por la ley, constituyan medidas necesarias, en una sociedad democrática, para la seguridad pública, la protección del orden, de la salud o de la moral públicas, o la protección de los derechos o las libertades de los demás."

6 "Artículo 10. Libertad de expresión. 1. Toda persona tiene derecho a la libertad de expresión. Este derecho comprende la libertad de opinión y la libertad de recibir o de comunicar informaciones o ideas sin que pueda haber injerencia de autoridades públicas y sin consideración de fronteras. El presente artículo no impide que los Estados sometan a las empresas de radiodifusión, de cinematografía o de televisión a un régimen de autorización previa. 2. El ejercicio de estas libertades, que entrañan deberes y responsabilidades, podrá ser sometido a ciertas formalidades, condiciones, restricciones o sanciones, previstas por la ley, que constituyan 


\section{DECISIÓN}

La apelación de Connolly fue desestimada por la Corte. Según el Tribunal, las expresiones producto de las creencias religiosas no tienen una protección mayor que el discurso común secular. De hecho, la Human Rights Act (1998)7 del Reino Unido permite la restricción de la libertad religiosa y de expresión. En este caso, la limitación de la libertad de expresión de la recurrente fue justificada, porque las imágenes eran manifiestamente indecentes y ofensivas. En opinión del Tribunal, cualquier juez razonable concluiría que las imágenes enviadas eran atroces y extremadamente provocativas. Además, la intención positiva de Connelly de provocar angustia y ansiedad a los destinatarios se podía deducir claramente del contexto (una especie de dolo directo). La restricción entonces estaba justificada por la protección de los "derechos de los demás", con arreglo al Artículo 9 de la CEDH. Finalmente, la Corte remarca que la condena de Connelly era proporcional al objetivo legítimo perseguido (evitar abusos de la libertad de expresión), fin que es necesario en una sociedad democrática. En otras palabras, su libertad de expresar sus opiniones no justificaba la ansiedad y la angustia que quería causar (balance y test de proporcionalidad). Desde otro punto de vista, Los destinatarios tenían derecho a no recibir dicho material ofensivo.8 Además, las farmacias no estaban en ninguna posición privilegiada para influenciar el debate público. Lo único que podría haberse logrado es que las farmacias dejaran de vender la píldora.

medidas necesarias, en una sociedad democrática, para la seguridad nacional, la integridad territorial o la seguridad pública, la defensa del orden y la prevención del delito, la protección de la salud o de la moral, la protección de la reputación o de los derechos ajenos, para impedir la divulgación de informaciones confidenciales o para garantizar la autoridad y la imparcialidad del poder judicial."

${ }^{7}$ La Human Rights Act (1988) incorporó ordenamiento jurídico del Reino Unido los derechos fundamentales contenidos en la CEDH. Esta ley concede una acción doméstica de tutela frente a la violación de un derecho de Convención. Así, la víctima puede recurrir a los tribunales del Reino Unido, sin la necesidad de acudir al Tribunal Europeo de Derechos Humanos. Esta ley ordena que los organismos públicos actúen de manera compatible con la CEDH. Los entes jurisdiccionales deben tomarla en cuenta cualquier decisión, y deben interpretar la legislación de forma harmónica con la Convención. Los tribunales pueden anular decisiones administrativas si adolecen de incompatibilidad con $\mathrm{CEDH}$. En el caso de la legislación, los tribunales sólo pueden hacer una declaración de incompatibilidad.

${ }^{8}$ El no ser turbado por este tipo de mensajes sería una especie derecho subjetivo absoluto confiere un poder a su titular que puede hacerse valer contra todos los demás sujetos; quienes tienen correlativamente un deber general de abstención. Es lo que, en la terminología de Hohfeld, sería una immunity. 


\section{COMENTARIO}

La inmigración y la multiculturalidad son parte de la realidad Latinoamérica. Este fenómeno tiene repercusiones en el ámbito religioso. De hecho, hay nuevas minorías cuyas manifestaciones religiosas pueden entrar en conflicto con las creencias predominantes. Este tipo de disputas pueden ser objeto de debate judicial. Paralelamente, Latinoamérica cuenta con nuevas constituciones producto de un proceso de democratización. Estas cartas fundamentales establecen la igualdad, la libertad religiosa y de expresión como principios fundamentales. Es natural que este proceso dialéctico contraponga posiciones conservadoras (muchas veces basadas en creencias religiosas) y liberales. El caso en comento refleja esa confrontación, de la cual se pueden extraer lecciones útiles para nuestro propio debate judicial. En el caso chileno, la discusión sobre el aborto y el matrimonio homosexual son claros ejemplos donde este caso puede ser invocado como precedente.

Connolly v DPP [2007] es uno de los más importantes casos sobre la aplicación de la CEDH en el Reino Unido. La Human Rights Act (1988) incorporó ordenamiento jurídico del británico los derechos fundamentales contenidos en la CEDH. Al mismo tiempo, este caso aplica la Malicious Communications Act de 1988 (MCA) que tipifica el delito de "enviar o entregar cartas (o mensajes de correo electrónico) u otra información con el fin de provocar angustia o ansiedad". Esta ley cubre, asimismo, las informaciones realizadas a través de los medios de comunicación social que tengan un sesgo "racial o religioso".9 En realidad, la MCA fue utilizada para sancionar a Veronica Connelly, quien se expresaba bajo una motivación religiosa, sin intensión de discriminar al receptor por sus creencias.

En palabras simples, la libertad de expresión es el derecho a declarar de ideas y opiniones sin ser objeto de censura o castigo (este derecho incluye también la libertad de

\footnotetext{
9 Sobre el asunto puede verse BLISS, Laura, "The crown prosecution guidelines and grossly offensive comments: an analysis", Journal of Media Law 9.2 (2017), pp 173-188; y COLLINGWOOD, Lisa \& other, "Offending and being offended online: vile messages, jokes and the law", Computer Law \& Security Review 31.6 (2015), pp 763-772.
} 
ISSN 0719-7160

información). La libertad de expresión es uno de los más relevantes derechos para proteger el proceso democrático y la transparencia del debate público, como el TEDH ha declarado en múltiples ocasiones. Esta libertad está garantizada en las constituciones, las legislaciones nacionales y tratados internacionales. Por supuesto, libertad de expresión no es un derecho absoluto, como declara el tribunal inglés en la sentencia comentada. Por lo tanto, hay algunas limitaciones generales que lo restringen como la injuria, la calumnia, las buenas costumbres, la instigación a la violencia, la divulgación de información clasificada, la privacidad, la seguridad nacional, etc. Esas excepciones se basan en harm principle,10 según el cual esta libertad sólo debe ser restringida para evitar daños a otras personas (los "derechos de los demás" en el lenguaje de la Convención) o a la colectividad en su conjunto.

Connolly v DPP (2007) aborda también el problema de si el discurso con motivaciones religiosas está más protegido que otros y hay más laxitud para considerarlo abusivo. Para el Tribunal está claro que no lo es. El intenso debate legal sobre el aborto, las diversas opiniones religiosas y los límites a la libertad de expresión en casos similares no son nuevos en el Reino Unido. En R (ProLife Alliance) v BBC, [2003] UKHL 23, el máximo tribunal británico respaldó la censura sobre la transmisión de un video de la Alianza ProLife que mostraba crudamente los resultados de un aborto. Básicamente, el asunto en ambos casos es el abuso de la libertad de expresión. El problema del abuso del derecho consiste en determinar si los titulares de éstos pueden ejercerlos arbitrariamente, y no generar ningún tipo de responsabilidad si se causa daño; o si, por el contrario, los derechos deben ser ejercidos dentro de ciertos límites $y$, si se daña a alguien ejerciéndolos, debe resarcírsele los perjuicios causados o, cuando menos, abstenerse de continuar con la conducta dañosa. El Tribunal parece entender que los derechos deben de ejercerse dentro de la finalidad que el legislador ha tenido en vista para crearlos. En el caso de la libertad de expresión, hay abuso cuando el discurso no ayuda a una de las finalidades de este derecho,

\footnotetext{
${ }^{10}$ Articulado por John Stuart Mill en su obra On Liberty (1859) y previamente establecido en la Declaración
} Francesa de los Derechos del Hombre y el Ciudadano (1789) como único límite a la libertad individual. 
la estimulación del debate público. Al mismo tiempo, hay abuso cuando el efecto perjudicial del ejercicio del derecho excede el efecto positivo del mismo. La CEDH considera expresamente el abuso de los derechos convencionales en su Artículo 17.11.

En el contexto europeo, hay dos sentencias domésticos relacionados con los límites del discurso religioso en Europa, uno en los Países Bajos y en Suecia. En los Países Bajos, un ciudadano de religión cristiana escribió “Jesús salva” en letras muy grandes en el techo de su casa. El gobierno local multó a ese ciudadano por infracciones a las regulaciones de planificación urbana, acto administrativo que el multado impugnó. En 2010, el Consejo de Estado holandés decidió que la orden administrativa para eliminar el eslogan era válida ya que no infringía los derechos fundamentales del accionante. En opinión del Consejo, la libertad de expresión y la propiedad no eran derechos absolutos.12 En Suecia, un pastor cristiano pronunció un sermón en su iglesia el cual afirmaba que la homosexualidad era un pecado y una anormalidad sexual. En su opinión, los homosexuales eran un "cáncer en la sociedad" y citaba específicos versículos de la Biblia. El pastor fue procesado por discurso de odio ya que, en opinión de la fiscalía, expresó desprecio por un grupo de personas basado en su orientación sexual. La fiscalía argumentó que el uso de textos bíblicos para amenazar o expresar desprecio hacia los homosexuales como grupo no estaba permitido y violaba derechos fundamentales. El acusado replicó que los Artículos 9 y 10 de la CEDH fueron infringidos por el proceso penal iniciado en su contra. En otras palabras, el discurso religioso estaba protegido por la libertad de expresión y de creencia. Según la Corte Suprema de Suecia, el sermón del acusado no tenía la intención de alentar el odio hacia las personas homosexuales. Consecuencialmente, permitir el enjuiciamiento criminal del pastor habría llevado a una restricción desproporcionada de su libertad para expresar su opinión sobre el significado de la Biblia, texto sagrado de su confesión religiosa.13 Todos

\footnotetext{
11 “Artículo 17. Prohibición del abuso de derecho Ninguna de las disposiciones del presente Convenio podrá ser interpretada en el sentido de implicar para un Estado, grupo o individuo, un derecho cualquiera a dedicarse a una actividad o a realizar un acto tendente a la destrucción de los derechos o libertades reconocidos en el presente Convenio o a limitaciones más amplias de estos derechos o libertades que las previstas en el mismo."

12 X. v Mayor and aldermen of Giessenlanden, BN1135; Gemeentestem 2010, 77.

${ }^{13}$ General Prosecutor v Green, Appeal judgment, Case B 1050-05, NJA (Nytt Juridiskt Arkiv) 2005 Section. XX.
} 
ISSN 0719-7160

estos casos pueden estimarse como antecedentes para futuras discusiones similares en Latinoamérica. 